edition provided in Appendix IV are the Series of mystagogical-theological teachings and explications, the Story of Susanna, the Homily on the Genealogy of the Holy Family, as well as the Stories on Old Testament themes. The publication also features a List of biblical characters of the Palaea Historica II (Wykaz postaci biblijnych w PH II, p. 383-388). Needless to say, the book opens with an Introduction (p. 9-16) and closes with a Conclusion (p. 309-314); it also has an ample Bibliography (p. 315-340) as well as summaries in Bulgarian (p. 389-392) and English (p. 393-396).

Without any doubt, the work by Małgorzata Skowronek will be of great interest to all students of the Slavia Orthodoxa cultural sphere, be it philologists or historians. It is a meaningful contribution to the research on the reception of Byzantine culture in the Slavic world. Its exceptional value lies in that it concerns the second Slavic translation of the Palaea - usually given the short shrift in the scholarship, where much more attention is paid to the Greek original and the first Slavic translation.

\section{BIBLIOGRAPHY}

Skowronek M., Palaea Historica. The Second Slavic Translation: Commentary and Text, trans. Y. Loske, Łódź 2016 [= Series Ceranea, 3].

Skowronek M., "Świat caly ma Cię za obrońcę". Michał Archanioł $w$ kulturze Słowian prawosławnych na Bałkanach, Łódź 2008.

Średniowieczne herezje dualistyczne na Bałkanach. Źródła słowiańskie, ed. et trans. G. Minczew, M. SкоWRONEK, J.M. Wolski, Łódź 2015 [= Series Ceranea, 1].

Maciej Dawczyk (Łódź)*

Translated by Marek Majer

${ }^{*}$ Uniwersytet Łódzki, Wydział Filozoficzno-Historyczny,
Katedra Historii Bizancjum

DOI: 10.18778/2084-140X.08.18

\title{
Libanios, Discours, t. III, Discours XI. Antiochicos, texte établi et traduit par M. CASevitz, O. LAgaCherie, notes complémentaires par C. SAliou, Les Belles Lettres, Paris 2016 [= Collection des Universités de France. Série grecque, 524], pp. CIII, 213.
}

$\mathrm{T}$ he book in question is the third volume containing Libanius's writings published in the renowned "Collection Budé" series edited by French philologists and historians: Michel Casevitz, Odile Lagacherie and Catherine Saliou ${ }^{1}$. This bilingual edition (the original Greek and the facing-page French translation, p. 1-74) is preceded with a detailed introduction (p. VII-LVII) and a comprehensive bibliography (p. LIX-CII) ${ }^{2}$. To accompany the

\footnotetext{
${ }^{1}$ Libanios, Discours, vol. II, Discours II-X, ed. et trans. J. Martin, Paris 1988 [= CUF.SG, 319]; Libanios, Discours, vol. I, Autobiographie (Discours I), ed. J. MARtin, trans. P. Petit, Paris 1979 [= CUF.SG, 256].

${ }^{2}$ The summary of the sources and the detailed and meticulously compiled list of modern scholarly litera-
}

translation, the editors provided the reader with a studious commentary (p. 75-197; double pagination), indexes, and maps. This edition is the most comprehensive of all available editions of Oration 11, which is certainly one of the most important sources for the history of Antioch on the Orontes.

ture on the subject (which is so dispersed in terms of its geographical and chronological distribution) are a manifest sign of the need for an annotated bibliography of the entire corpus of Libanius's works (perhaps following the approach of the recently published bibliography concerning the writings of Ammianus Marcellinus; F.W. Jenkins, Ammianus Marcellinus. An Annotated Bibliography, 1474 to the Present, LeidenBoston 2016 [= PHCAM]. 
The staggering number of opaque allusions contained in the text as well as its complex metaphors and similarly numerous topoi subject to the intricate principles of Greek rhetoric continue to perplex modern readers. A literal reading may easily lead us astray, hence the need for a commentary to provide the reader with a key to understand the oration. The French edition of this text stands out among its predecessors on account of its length and penetrative character of the commentary ${ }^{3}$. Most of it was prepared by Catherine Saliou, whose statements about the oration are summarised below.

${ }^{3}$ The earliest Russian and Polish translations are beautifully written and can be considered as masterpieces of translator's craft, but they lack a substantial commentary, including as they do only a general introduction and excessively cursory footnotes (at least by current standards). Seе: Ливаний, Похвала Антиохии (Orat. XI F.), [in:] Речи Либания, vol. II, trans. et ed. С. Шестаков, Казань 1916, р. 346-399 and Libanios, Mowa XI: mowa na cześć Antiochii, [in:] Libanios, Wybór mów, trans. et ed. L. MaŁUNowiczównA, Wrocław 1953, p. 7-81. The following two English translations are endowed with a greater amount of accompanying material (both include short introductions, the newer one is also extensively footnoted): Libanius' Oration in Praise of Antioch (Or. XI), trans. et ed. G. Downey, PAPS 103, 5 (1959), p. 652-686; Libanius, The Antiochicos: In Praise of Antioch, [in:] Antioch as a Centre of Hellenic Culture as Observed by Libanius, trans. A.F. NoRman, Liverpool 2000 [= TTH, 34], p. 3-65. An in-depth introduction and an impressive and detailed commentary was published with a translation into German: Libanios, $A n$ tiochikos (or. XI). Zur heidnischen Renaissance in der Spätantike, trans. G. FAtouros, T. KrIsChER, WienBerlin 1992, p. 286. For a translation into Spanish, see: Libanio, Discursos, vol. II, ed. et trans. Á. González GÁlvez, Madrid 2001 [= BCG, 292], p. 81-180 (Kindle edition, loc. 945-2870). The Spanish and English (by A.F. Norman) publications contain only basic commentaries drawing on a few classic studies by Downey, Festugière, Petit and Liebeschuetz. Only the German commentary can match the French in terms of its detailed and penetrative character. See also: A.J. Festugière, Antioche païenne et chrétienne. Libanius, Chrysostome et les moines de Syrie, Paris 1959, p. 23-37 (including paragraphs 196-271 translated into French) and Der Antiochikos des Libanios, trans. et ed. L. HugI, Solothurn 1919 (including paragraphs 1-131 translated into German).
The oration was delivered in its shorter version during the Olympic games taking place in Antioch in 356. The full version as we know it today has circulated in public since about 362 . This laudatory speech, a eulogy, was composed in keeping with the principles of epideictic rhetoric, presenting an idealised version of the reality it aimed to describe. Without overlooking the impact of earlier speeches in praise of cities (and in contrast to the earlier commentators), C. Saliou proves that Libanius was greatly influenced by the principles of epideictic rhetoric developed by Menander Rhetor (p. VII-XI) ${ }^{4}$.

Her analysis of the oration draws attention to the instances where panegyrical hallmarks can best be seen: the descriptions of local climate and landscape, the mythical origins of the city, its long history, the attitudes of the gods to Antioch, the character of its inhabitants, its social relations, the outlook of the city and the suburbs, and its food and water supplies (p. XI-XXXI).

About a third of the oration deals with the history of Antioch. Libanius is selective and manipulative in his presentation of historical facts (for instance, there is hardly anything about the city in the early imperial period), harnessing them to glorify Antioch and the Antiochenes. In order to convince his audience that Antioch had been an ancient city related to other Greek urban centres, Libanius referred to the city founders of the legendary past (Triptolemus of Argos, Casius of Crete, Cypriots and the Heraclids) as well as to historical figures, including Cambyses, Alexander the Great and Seleucus I Nicator. These references relate to legends which originated in the Hellenistic period without any solid historical grounds (e.g. the part played by Alexander the Great in the city's

\footnotetext{
${ }^{4}$ For the impact of epideictic tradition (including Menander Rhetor) on Libanius, see opinions of A.F. Norman (Libanius, The Antiochicos..., p. 4) and Á. González Gálvez (Libanio, Discursos, vol. II..., Kindle edition, loc. 981-982). On the other hand, Fatouros and Krischer omit Menander and state that: Das ist nicht zu verwundern, den von allen nachklassischen Autoren hat keiner einen größeren Einfluß auf Libanios ausgeübt als Aristides (Libanios, Antiochikos (or. XI)..., p. 14).
} 
foundation) or to purely hypothetical suppositions (e.g. the migrations of Cretans and Cypriots to Syria before the Hellenistic era). The past is thus merely a tool for creating an idealised image. However, the historical worth of Oration 11 should not be considered simply by judging its factual accuracy. The oration recreates the collective memory by referring to the origins of Antioch and to its distant past, but to some extent, in the section describing the city in the Hellenistic period, it also allows us to catch a glimpse of the official dynastic historiography of the Seleucid dynasty (p. XXXI-XLI).

Despite its clearly rhetorical nature, Oration 11 remains the best source for studying the urban planning and topography of Antioch in the year 356. Given that it would be rash to expect an objective rendering of the city's landscape in a eulogy, one has to pay special attention to the passages relating to individual, specific objects or places. In many instances, passages such as these are undeniably noteworthy historical documents. In any case, Libanius avoids using the names of objects and places for fear of making the speech appear incomprehensible to people who are unfamiliar with the topography of Antioch. Also, he may have demonstrated in this way his aversion to ordinary language. Another striking feature, resulting from the use of metonymy, is the use of the name and description of the main street in cases where references are made to the city as a whole. Some topographic and toponymic descriptions referring to the period before the foundation of the city and to the foundation itself result from urban memories rooted in specific urban spaces. However, some of the places described on such occasions are difficult to identify, and the referents used by Libanius have little in common with those commonly used, but result from a longer literary tradition (p. XLI-XLV).

Paul Petit stated that this oration, replete as it is with references to the past and the gods, may be interpreted as the pagan faction's manifesto; C. Saliou notes that this view has been disproved in contemporary scholarship. We cannot be sure about the content of the original speech delivered by Libanius during the games, an em- phatically pagan event dedicated to Zeus. However, most references to the gods in Oration 11 curiously look back to the past, while the name of Zeus, the patron of the games, is omitted altogether. It seems that Libanius takes a very careful approach to the paganism of his contemporaries. Oration 11 is certainly not a monument to the pagan's resistance; we should see it instead as an attempt at reaching a consensus and creating a common space for all inhabitants of the city despite its religious diversity. This work can also be seen as a testimony to the fragile stability achieved in Antioch by various religious groups (p. XLV-XLVII).

In addition to that, Oration 11 is also a source for the history of political ideas, which is due primarily to the central role that Libanius attributed to the city council. It replicates the views of at least some members of the city's elite and some emperors as well (note especially the case of Julian). The description of the curia is another element aimed to produce the image of Antioch as the most distinguished city among all others (Alexandria in particular) in the Roman Middle East (p. XLII-L).

The reception of Oration 11 went far beyond the traditional boundaries of late antique and mediaeval literature (note especially Choricius of Gaza, John Phocas, Nicolaus Mesarites, Bessarion), as can clearly be seen in the twentieth-century studies on urban planning (by M. Bosanquet, M. Poëte, and L. Mumford) where Libanius is viewed as the actual forerunner of modern urban thought (p. L-LIV). These considerations are indeed a novelty, given that we would look in vain for such views in earlier studies on Oration 11.

The topics addressed in the introduction are developed in the part prepared by C. Saliou which contains more detailed comments. That part consists of individual entries referring to specific paragraphs of the original text; explanatory notes are provided for about 230 paragraphs of the oration (the original is divided into 272 paragraphs). In keeping with the oration's composition, the first part of the commentary deals with the history of the city from its origins to the fourth century AD (p. 75-128). This section 
includes a long discussion of addenda et corrigenda to Libanius's vision of Antioch in the Hellenistic period and aims in particular to demythologise the role of Seleucus I in the city's history (for instance, critical attention is given to the status of the city as capital during his reign, the construction of porticoes along the main street, the use of elephants for laying out the grid system of the streets, the establishment of the cult of Zeus Bottaios, the adoption of the cult of Isis, and so on, p. 103-120). The second part of the commentary deals with the general questions concerning the daily functioning of Antioch during Libanius's lifetime (p. 128-197). For instance, C. Saliou slightly distanced herself from the earlier statements of P. Petit and noted that the terms $\chi о \rho \varepsilon \gamma i ́ a$ and $\lambda \varepsilon ı \tau o v \rho \gamma i ́ a$ are synonymous in Libanius's letters and orations and refer to organising hunts and providing heating to the baths (p. 77). Like many other contemporary researchers, C. Saliou disproves the earlier view of G. Tchalenko on the fundamental role of olive oil among the agricultural products of northern Syria. Olive oil was not the only alimentary product of Syria marketed far and wide by means of seaborne trade; contrary to Libanius's opinion, wine also played a significant role among the goods exported from the region. This particular question certainly requires further study, especially considering the fact that in late antiquity, in the light of the research conducted recently by Polish scholars, Syria ceased to export olive oil on a massive scale (it was traded at the time only in the neighbouring regions, particularly in Egypt, Mesopotamia and Hijaz) ${ }^{5}$.

The detailed commentary to individual paragraphs together with the introduction to the translation provide the reader with a comprehensive and coherent picture of our current knowledge about ancient Antioch. It is beyond doubt that no serious study on the history of this Syrian city can now be conducted without using this work of scholarship.

${ }^{5}$ T. Waliszewski, Elaion. Olive Oil Production in Roman and Byzantine Syria-Palestine, Warsaw 2014 [= PAM.MS, 6], p. 301-302, 307-311.

\section{BIBLIOGRAPHY}

\section{Primary Sources}

Der Antiochikos des Libanios, trans. et ed. L. Hugi, Solothurn 1919.

Libanij, Pochvala Antiochii (Orat. XI F.), [in:] Reči Libanija, vol. II, trans. et ed. S. Š ESTAKov, Kazan’ 1916, p. 346-399.

Libanio, Discursos, vol. II, ed. et trans. Á. GonzÁlez GÁlvez, Madrid 2001 [= Biblioteca Clásica Gredos, 292], p. 81-180 (Kindle edition, loc. 945-2870).

Libanios, Antiochikos (or. XI). Zur heidnischen Renaissance in der Spätantike, trans. G. Fatouros, T. KRISCHER, Wien-Berlin 1992.

Libanios, Discours, vol. I, Autobiographie (Discours I), ed. J. Martin, trans. P. Petit, Paris 1979 [= Collection des Universités de France. Série grecque, 256].

Libanios, Discours, vol. II, Discours II-X, ed. et trans. J. Martin, Paris 1988 [= Collection des Universités de France. Série grecque, 319].

Libanios, Mowa XI: mowa na cześć Antiochii, [in:] Libanios, Wybór mów, trans. et ed. L. MaŁunowiCZównA, Wrocław 1953, p. 7-81.

Libanius, The Antiochicos: In Praise of Antioch, [in:] Antioch as a Centre of Hellenic Culture as Observed by Libanius, trans. A.F. Norman, Liverpool 2000 [= Translated Texts for Historians, 34], p. 3-65.

Libanius' Oration in Praise of Antioch (Or. XI), trans. et ed. G. Downey, "Proceedings of the American Philosophical Society” 103, 5 (1959), p. 652-686.

\section{Secondary literature}

Festugière A.J., Antioche païenne et chrétienne. Libanius, Chrysostome et les moines de Syrie, Paris 1959.

Jenkins F.W., Ammianus Marcellinus. An Annotated Bibliography, 1474 to the Present, Leiden-Boston 2016 [= Philological and Historical Commentary on Ammianus Marcellinus].

Waliszewski T., Elaion. Olive Oil Production in Roman and Byzantine Syria-Palestine, Warsaw 2014 [Polish Archaeology in Mediterranean. Monograph Series, 6].

Pawet Filipczak (Łódź)*

\footnotetext{
* Uniwersytet Łódzki, Wydział Filozoficzno-Historyczny, Katedra Historii Bizancjum
} 